\title{
DARNUMAS IR JO TEIKIAMA NAUDA ORGANIZACIJOMS
}

\author{
Ligita Šmanskiené ${ }^{1}$, Arnoldas Petrulis $^{2}$
}

Klaipedos universitetas (Lietuva)

\begin{abstract}
ANOTACIJA
Pastaruoju metu darnaus vystymosi terminai ịvairiuose moksluose, atliekant tarpdisciplininius tyrimus, gana dažnai vartojami, tačiau vis dar pasigendama ne tik išsamesnio paaiškinimo, kas yra darnus vystymas, darni organizacija, darnus verslas, bet esama žmonių, kurie kategoriškai priešinasi darnaus verslo vystymui. Šiame straipsnyje analizuojamos prielaidos, galinčios pagrịsti darnaus vystymosi naudą organizacijoms. Pateikiamos ir analizuojamos darnios organizacijos sampratos ir nauda organizacijoms, kurios sieks tapti darnios.
\end{abstract}

PAGRINDINIAI ŽODŽIAI: darnumas, organizacija, nauda.

JEL KLASIFIKACIJA: Q56, Q 01, M 10

Ivadas

Jau seniai išsivysčiusiose pasaulio šalyse ryškus poreikis išsaugoti dar išlikusią nepažeistą aplinką (kur ịmanomą - ją atkurti) ir garantuoti tolesnį žemės gyventojų (ne tik žmonių) išlikimą ir vystymąsi. Norint tai pasiekti, būtina ịgyvendinti visų žmogaus veiklos sričių - gamybos, paslaugų, rinkodaros, vartojimo, valstybès valdymo, tarptautinių ekonominių ir visuomeninių organizacijų veiklos - pokyčius. Matome, kad vis svarbesnị vaidmenị pasaulinėje darnaus vystymosi ịgyvendinimo politikoje (politika - tai bendro žmonių gyvenimo visuomenèje organizavimo ir nuolatinio reguliavimo veikla) atlieka savanoriškos verslo pastangos, kurias tiesiogiai ir netiesiogiai veikia visuomenès požiūris į jų veiklą. Nors organizacijų vadovybè, be abejo, supranta, kad reikia įvertinti ir prisitaikyti prie naujų pokyčių, nuolat stebèti konkurentus, jų veiklą, vis ieškoti naujų išteklių, kartu atsižvelgti į aplinkosaugos reikalavimus. Tai organizacijoms nèra lengva. Be to, vis dar esama organizacijų vadovų, kurie vadovaujasi tik ekonomine, neretai - savanaudiškumo logika. Tokie vadovai mano, kad bet kuri investicija, reaguojant ị aplinkosaugos reikalavimus, nekalbant apie socialinius darbuotojų ar bendruomenès poreikius, yra tik lěšų švaistymas. Todèl tampa svarbus mokslinis klausimas, kaip pagrįsti darnios organizacijos naudą ir pakeisti minètų vadovų mąstymą. Beje, darnios organizacijos kūrimo klausimai aktualūs ir tiems vadovams, kurie suvokia darnumo naudą, bet nežino, kaip to pasiekti. Sparčiai vykstant ekonomikos, technologijų, verslo išorinių ir vidinių aplinkų pokyčiams, darnus organizacijos vystymas tampa viena svarbiausių ir aktualiausių organizacijos problemų: kaip tai užtikrins organizacijos

Ligita Šimanskienè - profesorè, daktarè. Klaipėdos universiteto Socialinių mokslų fakulteto Vadybos katedra, Regioninės politikos ir planavimo centras. Moksliniai interesai: organizacinès kultūros tyrimai, ISA, konfliktų tyrimai organizacijose, komandinis darbas, kultūrų skirtumai, darnus regionų ir organizacijų vystymas

Adresas: Minijos g. 155, LT-93185 Klaipeda

El. paštas: ligita.simanskiene@gmail.com

Tel:. +37046398 596; +37046398597

2 Arnoldas Petrulis - verslo vadybos magistrantas. Klaipėdos universiteto Socialinių mokslų fakulteto Vadybos katedra. Mokslinių interesų kryptys: organizacijų valdymas, vadovavimo stiliai

Adresas: Minijos g. 155, LT-93185 Klaipeda

El. paštas: arnius1971@gmail.com

Tel.: +370 67344429 
konkurencingumą? Kuo tai padès pačiai organizacijai jos veikloje? Šiuolaikinès ekonomikos sąlygos, stiprèjanti konkurencija, nuolat kintančios veiklos aplinkybès, riboti gamtos ištekliai verčia organizacijas nuolat peržiūrèti savo veiksmus, numatyti naujus tikslus ir jų siekimo būdus. Planuodama veiklą, organizacija gali igyti pranašumą, jeigu jos vadovai gerai susipažinę su rinkoje vykstančiais procesais ir geba numatyti galimus jų padarinius, išsikeldami trumpalaikius ir ilgesnès perspektyvos tikslus, suderinę aplinkosauginius, ekonomikos ir socialinius aspektus. Todèl darnus organizacijos vystymas apima organizacijos suformuluotą ateities viziją, prisiimamą misiją, siekiamus tikslus, išsikeltus uždavinius ir numatytus veiksmus, įvertinus alternatyvas, kurie padètų visą tai paversti tikrove, nauda ne tik konkrečiai organizacijai, bet ir visuomenei.

Darbo objektas - darni organizacija.

Darbo tikslas: atskleisti darnumo naudą organizacijoms.

Darbo uždaviniai:

- pateikti prielaidas, skatinančias kurti darnias organizacijas;

- apibrezžti darnios organizacijos sampratą ir pagrịsti naudą organizacijoms tapti darniomis.

Darbo metodai: remiantis užsienio ir Lietuvos mokslininkų tyrimais, taikant literatūros analizès ir sintezès, stebejjimo metodus, susisteminti duomenys ir sukurti paveikslai, pagrindžiantys darnios organizacijos naudą. Taikytas stebejjimo metodas ypač tinka rinkti duomenis, atliekant žmonių elgesio ir organizacijų tyrimus. Dažniausiai stebèjimo vienetas yra ne pavienis žmogus, o jų grupė: šiuo atveju darnia veikla užsiimančios organizacijos. Stebejjimo, kaip duomenų rinkimo metodo, taikymas remiasi prielaida, kad kartais geriau stebėti, kas vyksta, o ne klausti žmonių, kas vyko. Stebėdamas tyrèjas suvokia sąveikų ịvairovę, apie kurią informantai nekalba, susidaro visapusišką vaizdą apie tiriamą problemą.

\section{Darnios organizacijos kūrimo prielaidos}

Darnų vystymąsi galima apibrèžti, kaip sisteminiu mąstymu paremtą vystymosi filosofiją, kurios esmė pamatiniai gamtos dėsniai, kurių žmogus neturètų pažeisti, norėdamas užtikrinti sistemos patvarumą ir žmogaus tęstinumą šioje planetoje, kartu užtikrinant socialinį teisingumą ir ekonominę gerovę. D. Leuenbergerio (2006) teigimu, biologinè įvairovè, funkcinis atsparumas, darbo našumas, socialinė gerové, pilietiškumas, socialinis teisingumas yra praktiniai darnaus vystymo komponentai. Todėl akivaizdu, kad darnūs ekonominiai sprendimai negali būti neekologiški, taigi jie galimi, tik jei įvyks fundamentalūs žmonių vertybinių nuostatų pokyčiai, susikurs nauja etika, naujas požiūris ị gamtą, numatantis visų mūsų atsakomybę, išsaugant sveiką santykị su gamta (Čiegis, Gavenauskas, 2005; Štreimikienè, Vasiljevienè, 2004). Darnus vystymasis tampa vis svarbesnis planuojant gamybą, nes turi būti atsižvelgta ị tokias sritis, kaip visuotinis klimato atšilimas, vaikų įdarbinimo ir socialinių bei aplinkos apsaugos standartų laikymasis. Dažniausiai darnus vystymasis apibūdinamas kaip visapusiškas trijų dimensijų (ekonomikos, ekologijos, socialinių reikalų) ir jų ilgalaikių perspektyvų nagrinèjimas. Tinkami rodikliai ir kokybès metodų bei procedūrų taikymas yra būtini vertinant organizacijos procesus darnaus vystymosi požiūriu (Jochem, 2011, p. 130). Darnų verslą užtikrinantys veiksniai yra ne tik ekonominiai, bet ir susiję su aplinkos ištekliais, socialine gerove bei stabilumu. Verslo sektorius vaidina pagrindinị vaidmeni, sprendžiant tokias problemas kaip ekologinè žala vietiniu, regioniniu ir globaliu mastu (Bruno, Karliner, 2002; Clifton, Amran, 2010). Aplinka ir verslas yra glaudžiai susiję, o ilgalaikè verslo sèkmè priklauso nuo to, kaip organizacija geba darniai integruotis ị aplinką ir jausti visuomenès socialines nuotaikas. Istoriškai kreipęs dėmesị tik ị pelno kaupimą, šiuolaikinis verslas jau turi atsižvelgti ị aplinkos tausojimą ir platesnius socialinius interesus, nes tai yra verslo sékmès pagrindas, be kurio verslas negalès toliau vystytis.

Šiuo metu sẻkmingos verslo organizacijos ,,auklèja, šviečia“ vartotojus. Tai jos daro dalyvaudamos aplinkosauginėse ir kitose pilietinėse akcijose, neteršdamos gamtos ir paaiškindamos vartotojams, kodèl tai naudinga visuomenei. Taip skatinamas etiškas ir aplinkosauginis vartojimas, kuris, viena vertus, gali atrodyti organizacijoms nenaudingas, kita vertus, tai puiki reklama, padeda išsiskirti iš kitų panašia veikla užsiimančių organizacijų. Taigi reikia dirbti tokiomis kryptimis (Juščius, Šneiderienė, 2013, p. 72): 
- Užtikrinti konkrečių gaminių rūšių gamybos kiekį, kurio pakaktų tam tikrai rinkos nišai užimti. Visų pirma organizacija turi gaminti tas prekes ir teikti tas paslaugas, kurios tam tikru laikotarpiu yra paklausios. Kitaip tariant, kuo geriau organizacija tenkina visuomenès lūkesčius ir poreikius, tuo tvirčiau ji ịsitvirtina visuomeneje ir veikla tampa pelningesnè.

- Kontroliuoti ir gerinti gaminio savybes, mažinti gamybos sąnaudas, siekiant gauti planuotą pelną ir sumažinti nuostolių riziką sumažejus rinkos kainoms.

- Verslo sẻkmé dažniausiai priklauso nuo to, kaip sugebama padaryti savo gamini patrauklų, t. y. kaip pateikiamas gaminio išskirtinumas.

Atsižvelgdama ị visuomenès lūkesčius, organizacija susikuria geresnị ịvaizdị rinkose, kaip pačios organizacijos išskirtini pranašumą. O ekologiško gaminio išskirtinumą dažniausiai atskleidžia ekologinio ženklo pridèjimas prie etiketès (ekologinè etiketè), tai suteikia produkcijai pridètinę vertę (Esty ir Winston, 2009; Orlitzky, Siegel, Waldman, 2011). Šiandieninis vartotojas prekès ženklą tiesiogiai sieja su paslaugos ar prekès pardavejju. Ekologinio produkcijos pranašumo išnaudojimas reklamoje ne naujiena, tačiau dabar jų vaidmuo prekès ženklo kūrimo ir plètojimo procese gerokai išaugo. Tokia rinkodaros strategija duoda teigiamų rezultatų, nes padeda lengviau pasiekti abipusę naudą įmonei ir pirkèjui / vartotojui dèl prekès ženklo reputacijos, kaip vieno iš jos vertės suvokimo elementų (Bakanauskas, Vanagienė, 2012, p. 15). Teiginys apie darnią subjektų plètrą suformuluotas kaip samprotavimų išvada, o ne kaip reiškinio tiesioginio stebejjimo padarinys. Pabrěžtina, kad tai būdinga socialiniams mokslams, kur stebimi pokyčiai numatomi remiantis stebèjimu pagrịstais modeliais. Todèl, teigtina, kad modeliavimo metodai būtų tikslūs, jie turi būti metodologiškai pagrịsti ir atsižvelgta i jų daromą ịtaką. Tačiau ne visada įmanoma iš anksto įvardyti, tam tikra ịtaka yra teigiama ar neigiama, nes tai priklauso nuo tuo metu vertinamos organizacijos (Bartkus, Grunda, 2011, p. 32). Todèl siūloma galimas ịtakas sugrupuoti ị teigiamą, neigiamą ir situacinę. Taigi verslo darnumo daromos įtakos turi poveikị aplinkai:

- Neigiama įtaka: tarša, produktų gyvavimo ciklo pabaigos tarša, diskriminacija, korupcija, išteklių mažejjimas, medžiagų eikvojimas, vaikų darbas ir baudos.

- Teigiama įtaka: darbuotojų mokymai, neigaliųų įdarbinimas, darbuotojų, neturinčių darbo patirties, ịdarbinimas, priešpensinio amžiaus darbuotojų įdarbinimas, darbo saugumas, draugiška darboviete, profsajungos, mokami mokesčiai, mokamas atlyginimas, pelnas ir labdara.

- Situaciné įtaka: produktas ar paslauga, produkto tiekimas ar paslaugos teikimas apibrèžtai visuomenei (pvz., išskirtinis prabangus gaminio modelis).

Remiantis M. Charterio, K. Peattie, J. Ottmano ir M. J. Polonskio (Butkutė, Gotautienė 2011, p. 104) pateiktu modeliu, norėdama pasiekti išskirtini pranašumą ekologinès rinkodaros požiūriu, organizacija turi igyvendinti šiuos uždavinius:

- organizacijos vidaus nuostatų, orientuotų i aplinkos apsaugą, sukūrimas ir paskelbimas;

- aplinkosaugos veiksnių îvertinimas ir nuolatinis atskaitingas tikrinimas: būtina įvertinti pasiektus rezultatus (šių ataskaitų dẻka įmonès gali siekti būti sertifikuotos atitinkamų tarptautinių organizacijų, kurių suteikiami sertifikatai plačiai pripažistami ir ne tik atskleidžia organizacijos laimèjimus tam tikroje srityje, bet ir padeda jai kurti teigiamą ịvaizdị);

- tikslų nustatymas ir veiklos programų rengimas;

- atsakomybès nustatymas;

- tolygiai pritaikomas išteklių skyrimas;

- darbuotojų mokymai; darbo jègos ugdymas - tai viena iš prielaidų didinti darbo veiksmingumą, kurti pridedamają vertę, kurią lemia tam tikras darbo našumas, igalinantis darbo jègą sukurti didesnę vertę nei jos pačios vertè (Pilipavičius, 2012, p. 196);

- veiklos programų stebèsena;

- ekologinio požiūrio įvertinimo rodiklių nustatymas; 
- aplinkosauginès visumos suderinimas su organizacijos verslo valdymo sistema;

- aplinkosauginiais reiškiniais suinteresuotų šalių įtraukimas.

V. Juščius ir A. Šneiderienè (2013, p. 70) pasiremia pačia paprasčiausia savanaudiško racionalumo teorija, kurioje teigiama, kad prisidejjimas prie visuomenès vystymosi, tvirtos bendruomenès formavimo bus naudingas verslui ilgalaikejje perspektyvoje. Remiantis tikslesniu šios teorijos apibrėžimu, savanaudiškas racionalumas remiasi dviem ịžvalgų kryptimis:

- Visuomenè tikisi, kad verslas, turẻdamas didelius finansinius išteklius ir galios, turètų duoti grąžos visuomenei, kitaip bus priimtos reguliavimo taisyklès ar net bus galimas vartotojų boikotas.

- Kitas teiginys yra tas, kad verslo socialinè veikla (kitaip dar vadinama įmonių socialinès atsakomybès, toliau - İSA, praktika) lems verslo sékmę, pritraukiant vartotojus ir darbuotojus, klientus, tiekejjus, bus sukurta geresnè aplinka, atsižvelgta ị suinteresuotujų grupių poreikius, be to, tokioms i̇monèms bus palankesnès ir valstybės institucijos.

Taigi pateikiami veiksniai, kaip sėkmingo verslo prielaidos, yra šie: visuomenės vystymasis, stiprios bendruomenès formavimas, regiono išsivystymas, geresnè veiklos aplinka, palankesnis valstybių institucijų požiūris, taip pat visų šių veiksnių kartu su verslu, kaip bendros ekonominės veiklos dalyvių, darnus bendradarbiavimas (Juščius, Šneiderienè, 2013, p. 70).

\section{Darnios organizacijos samprata ir nauda}

R. Čiegis ir R. Grunda (2007, p. 24-25), apibendrindami mokslo darbus, skiria šias darnaus verslo ir darnios organizacijos sampratas:

- UNCTAD darnaus verslo samprata darnų verslą apibūdina kaip verslą, kuris palieka aplinką ne blogesneje situacijoje kiekvieno finansinio periodo pabaigoje, nei ji buvo to finansinio periodo pradžioje; teigia, kad jei įmonè nori tarpti darnia, ji turi stengtis, kad jos įtaka aplinkai per finansinius metus nebūtų neigiama.

- „Geros korporacijos chartija“, nustačiusi 21 ịsipareigojimą, kurie suskirstyti ị penkias ịmonès veiklos sritis: darbuotojai, pirkèjai, tiekejjai, bendruomenè-aplinka, akcininkai-finansuotojai. Ši chartija susieja visas suinteresuotuju šalių sąveikas. Parengtos socialiai atsakingo verslo nuostatos gali būti taikomos ir kaip darnų verslą apibūdinantys požymiai.

- VALDEZ (pavadinta po 1989 m. ịvykusios tanklaivio „Exxon Valdez“ avarijos), 1992 m. pervadinta i CERES (nepelno siekiančios kompanijos, kuri skleidžia darnumo idèjas, sukūrè dešimt VALDEZ pamatinių nuostatų) principai, apimantys biosferos apsaugą, darnų natūralių išteklių naudojimą, taršos mažinimą, saikingą energijos naudojimą, saugių gaminių gamybą ir paslaugų teikimą, žalos atlyginimą bei reikalaujantys, kad ịmonès ị direktorių tarybą paskirtų aplinkosaugos ekspertus ir kad atliktų bei skelbtų metinị atitikimo VALDEZ (CERES) principams auditą;

- ICC verslo chartija už darnų vystymąsi, kurią sudaro 16 nuostatų, apimančių svarbias sveikatos, saugumo ir gaminių valdymo sąvokas ir suteikiančių verslui pagrindą aplinkos vadybai. Tai leidžia pasiekti pagrindinį chartijos tikslą - kad kuo daugiau įmonių pasišvęstų gerinti aplinkosauginę veiklą pagal ICC verslo chartijos principus, tam skirtų vadybos personalą, vertintų savo pažangą ir apie ją praneštų darbuotojams bei visuomenei;

- IISD darnaus verslo principai - Kanadoje ịsikūrusio Tarptautinio darnaus vystymosi instituto sukurti principai, sugrupuoti ị tris dalis: vidinę darną, išorinị patikimumą ir savo išteklių išnaudojimą.

- St. Gallen vadybos koncepcija, kurioje vadybos tikslai aiškiai skiriami ị tris valdymo lygmenis: normatyvinį, strateginị ir operatyvinį. Remiantis šia koncepcija, įmonės veikla pagrịsta jos ateities vizija, o pritaikant šią vadybos koncepciją darnaus vystymosi valdymui ịmonèje, ji veikia pagal darnios įmonès viziją, kuri kreipia įmonès veiklą tiek veiklos ir gaminių ekologinio tobulinimo kryptimi, tiek ị santykius su suinteresuotomis grupemis. 
- G. Winterio vadybos modelis, pagrịstas samprata, kad kiekvienas ịmonės darbuotojas yra didžiulio bendrovės organizmo „gyvoji ląstelë“ ir prisiima visapusišką bendrovės aplinkosauginę atsakomybę.

- Jungtinių Tautų Pasaulinio susitarimo socialiai atsakingo verslo nuostatos, kurių turètų laikytis įmonès, remiančios socialinę atsakomybę. Šios 10 nuostatų suskirstytos ị keturias grupes: žmogaus teisès, darbuotojų teisès, aplinkos apsauga ir kova su korupcija.

Egzistuoja nuomonè, kad pačioms organizacijoms gali būti sudètinga apibrèžti darną, darnų vystymąsi, darnų verslą ar organizaciją. Todèl pirmiausia minètina ši darnaus verslo ir darnios organizacijos teorinè samprata, tai yra darnumas per organizacijos ryšius su išteklių prieinamumu ir naudojimu, vèliau formuojant atsakingo verslo sampratą ir kt. Kadangi išoriné aplinka ir organizacijos yra glaudžiai susijusios, ilgalaikẻ organizacijų sékmé priklauso nuo to, kaip darniai ji geba suartèti ir įsilieti ị aplinką bei jausti suinteresuotụjų šalių socialines nuotaikas (Křupka, Provazníkova, 2013). Kad organizacija jaustų socialines nuotaikas, gali padèti užsimezgę bendradarbiavimo ryšiai tarp ịvairių ekonominès veiklos dalyvių, tai vienas pirmuju žingsnių, pradedant organizacijai vertinti darnaus vystymosi nuostatas (Brower, 2011). Todèl svarbu suvokti, kad jei organizacija nori užsitikrinti ilgalaikị visuomenès pritarimą ir pasitikèjimą, ji turi atlikti savo gaminio ekologinị ištyrimą visais jo gamybos, platinimo ir naudojimo laikotarpiais ir ịvertinti visas galimas aplinkosaugines bei technologines pasekmes. Sukurtas gaminys gali užtikrinti organizacijos veiklos gyvybiškumą ir ateitį, kuris kokybinę išraišką igauna gamybos procese (ištekliai - žaliava - gaminys - prekè - pajamos - investicijos), sukuriant pridètinę vertę, kad gaminys būtų pelningas (Pilipavičius, 2012, p. 196). Svarbu organizacijos veikloje ne tik laikytis darnaus vystymosi principų, bet ir apie tai pranešti tikslinèms su organizacija susijusioms grupėms. Darnios veiklos viešinimas padidina organizacijos veiklos skaidrumą ir visuomenès pasitikèjimą, o savanoriška aplinkosauginè ir socialinè veikla tampa svarbiu veiksniu, gerinančiu organizacijos ịvaizdị ir didinančiu jos vertę.

Organizacijai darnus vystymas reiškia verslo strategijų ir veiksmų, kurie šiandien patenkina organizacijos ir jos suinteresuotų šalių poreikius, taikymą, kartu apsaugo ir didina žmonių ir gamtos išteklius, kurių reikès ateityje (Čiegis, 2008). 1 lentelëje pateiktos kelių autorių darnios organizacijos sampratos.

1 lentele. Darnios organizacijos sąvokos

\begin{tabular}{|c|c|}
\hline Autoriai & Sąvoka \\
\hline Z. Atkočiūnienè, R. Radiunaitė (2011) & $\begin{array}{l}\text { Darni organizacija yra ta, kurioje gamta ir žmonès yra tinkamai } \\
\text { ivvertinami, tai sukuria didelị konkurencinị pranašumą }\end{array}$ \\
\hline L. Šimanskienè, J. Paužuolienè (2011) & $\begin{array}{l}\text { Darni organizacija - tai darnumas, apibrěžiamas per } \\
\text { organizacijos ryšius su išteklių prieinamumu bei naudojimu, } \\
\text { kuriant atsakingo verslo sampratą }\end{array}$ \\
\hline R. Čiegis, R. Norkutè (2012) & $\begin{array}{l}\text { Organizacijos, siekiančios savo veikloje darnumo, negali } \\
\text { ignoruoti nei vienos iš darnaus vystymosi dimensijų - integracija } \\
\text { turètų apimti visas veiklas įmonėje ir už jos ribų, siekiant } \\
\text { igyvendinti nepertraukiamą socialinį darnumą }\end{array}$ \\
\hline D. Lodienè (2011) & $\begin{array}{l}\text { Darni organizacija - tai puiki terpè kūrybiškumui, naujoms } \\
\text { idėjoms ir pažangai }\end{array}$ \\
\hline Z. Atkočiūnienè (2013) & $\begin{array}{l}\text { Darna organizacijoje reiškia daugiau nei vieno ar kito principo } \\
\text { igyvendinimą, tai požiūrių ir elgsenos transformacija, kuri laikui } \\
\text { bėgant investuotą kapitalą paverčia darniu pelnu }\end{array}$ \\
\hline
\end{tabular}

Šaltinis: sudaryta darbo autorių

Darni organizacija nèra savaiminis reiškinys. Tam būtina sukurti tinkamas sąlygas: nustatyti darnos iniciatyvų organizacijoje veiksnius, juos skatinančią ir palaikančią valdymo sistemą, nuolat juos plètoti ir tobulinti (Atkočiūnienè, Radiunaitė, 2011, p. 56). Darni organizacija yra puiki terpè plètoti pažangą, kai vadovybès nuolat skatinamas personalas gali tobulinti esamas technologijas ir kurti naujas. Todèl siekiant 
skatinti pažangą, pirmiausiai turime sukurti darnią organizaciją. Skatindami darnių organizacijų gimimą ir vystymąsi, savo ruožtu skatinsime pažangą (Lodienè, 2011, p. 170).

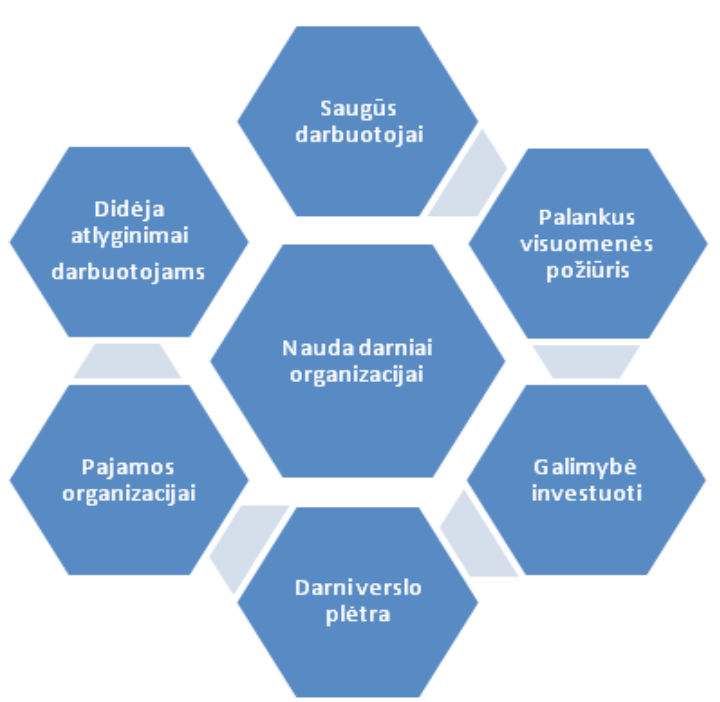

1 pav. Nauda darniai organizacijai

Šaltinis: sudaryta autorių

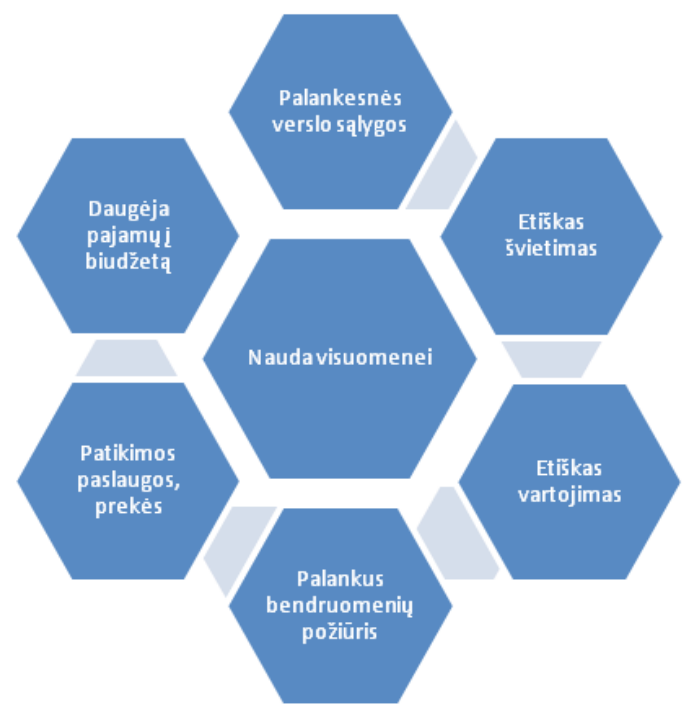

2 pav. Nauda visuomenei

Šaltinis: sudaryta autorių

Pateiktuose paveiksluose (1 ir 2 pav.) matome pavaizduotas naudas organizacijai ir visuomenei. Jeigu organizacija vadovaujasi darnumo principais, jos darbuotojai jaučiasi saugūs (pvz., organizacijoje vykdomi aplinkos apsaugos reikalavimai, atsižvelgiama į ekonominius ir socialinius darbuotojų poreikius, laikomasi atostogų, poilsio ir darbo režimo, mokama alga, laikantis darbo ir etikos kodeksų reikalavimų, nediskriminuojama pagal amžių, lytị ir pan.). Apie tokią organizaciją sužino visuomenè ir taip suformuojamas palankus visuomenès požiūris, skatinantis akcininkus investuoti. Turint darbuotojų pasitikejjimą ir daugiau lèšų, galima darniai plèsti verslą, t.y. investuoti ị aplinkai palankias naujas technologijas, naujo produkto kūrimą. Tai lemia pajamas organizacijai, pardavus pagamintą produkciją ar suteikus paslaugas. Gavus daugiau pelno, organizacijų vadovybė darbuotojams gali mokèti didesnes algas, taikyti darbuotojams materialines ir nematerialines motyvavimo priemones. Taip ratas apsisuka ir matome, kad darbuotojai gali jaustis saugūs, būti kūrybiški, siekdami ne tik asmeninès naudos, bet ir naudos organizacijai. Vis dèlto didžiausia paskata tokiems darbuotojams - galimybė dirbti darnioje organizacijoje: matydami, kad organizacijoje vystomas darnus verslas, žinodami, kaip, kur ir ị ką investuojama, kam suteikiama parama, jie didžiuojasi, kad gali dirbti organizacijoje, kur paisoma jų ir bendruomenès interesų. 2 paveiksle pavaizduota nauda visuomenei, jei šalyje ar regione, mieste esama darnių organizacijų. Instituciniu požiūriu, būtent tokioms darnioms organizacijoms sudaromos palankesnès verslo sąlygos. Darnios organizacijos, pateikdamos ekologiškus ar aplinkai nekenksmingus gaminius ar teikdamos tokias paslaugas, ugdo vartotojus, siūlydamos kitokị, darnų požiūrị i gyvenimą. Taip skatinamas etiškas ir taupus vartojimas, kas sukuria palankų bendruomenių požiūrị. Esant palankiam požiūriui, perkamos prekès ar naudojamasi būtent šių organizacijų paslaugomis, nes jomis pasitikima, tikima, kad jos negali pateikti nekokybiškų prekių, neišnaudoja vaikų darbo, neišnaudoja savo darbuotojų. Taigi tos organizacijos uždirbdamos daugiau, daugiau sumoka mokesčių valstybei, o tai naudinga visai visuomenei.

Siekiant nustatyti ir pagrịsti darnumo naudą, reikia neužmiršti visuomenès, kitaip tariant, atskleisti ir socialinius poreikius. Viena vertus, socialinis auditas yra būdas visai visuomenei ịsitikinti, kiek verslo įmonè dera su aplinka produktų ir paslaugų, aplinkosaugos, žmonių išteklių požiūriu. Kita vertus, tai būdas pačiai įmonei įsivertinti, kaip ịgyvendinami jos iškelti socialiniai tikslai (Dagilienė, Gokienè, 2012, p. 47). Ekologiškų gaminių gamintojai gali pasiekti pranašumą prieš kitus, jei savo veiklą plètotų būtent šia linkme ir informuotų apie tai potencialius vartotojus. Verslo ir visuomenès interesų suartejjimas daro ịtaką verslo sprendimų prièmimui, todèl organizacijos veikla transformuojama per kuriamą produkto pridètinę vertę. 
Etiškas vadybinių sprendimų prièmimas formuojant, kuriant ir naudojant išteklius, užtikrina konkurencini pranašumą, kuris leidžia plètoti darnų verslą (Гаврилов, 2012, с. 18):

- Turi įtakos organizacijos konkurencingumui.

- Padeda tausoti organizacijos išteklius ir ugdyti darbuotojų kompetencijas.

- Pagrindžia teisètą organizacijos veiklą bendruomenèje (visuomenèje).

Naudą visuomenei, organizacijai tapus darnia, D. B. Reiser taip apibręžia: teikti asmenims ar bendruomenėms produktus ar paslaugas taikant palankią kainodarą; skatinti palankias verslo sąlygas asmenims ar bendruomenėms, kuriančioms verslą; išsaugoti arba pagerinti aplinką; gerinti žmonių sveikatą; skatinti meno, mokslo ar žinių pažangą; didinti kapitalo srautus ị veiklą, kuri naudinga visuomenei, arba ị bet kurias kitas tikslingas veiklas, ypač nustatant konkrečią naudą visuomenei ar aplinkai (Reiser, 2011, p. 597).

Taigi apibendrinant galima teigti, kad darnus organizacijos vystymas - tai abipusé nauda, teikiama tiek organizacijai, kuri kuria ir pletoja savo verslą, tiek bendruomenei (visuomenei), kuri turi gyventi šalia savo veiklą plètojančios organizacijos, o gal net joje dirbti. Visų ekonominès veiklos dalyvių darna leidžia išvengti skaudžių padarinių (vieniems - ekonominių, kitiems - ekologinių).

Išvados

Darnaus organizacijos vystymo prielaidos susikuria skatinant savanoriškai besikeičiantị požiūrị ir elgesị socialiniais, aplinkosauginiais ir ekonominiais aspektais: noras užsitikrinti gerovę ir prisiimti atsakomybę, kaip santykis su dabartimi ir ateitimi, suteikiant galimybę ir kitiems užsitikrinti vystymąsi ir gerovę tiek dabar, tiek ateityje.

Darnumo teikiama nauda organizacijoms - ilgalaikis visuomenès pritarimas ir pasitikèjimas, palankus organizacijos ịvaizdis, jos gaminių ar teikiamų paslaugu paklausa, užtikrinantys jos tolesnị vystymą ir galimybę dirbti pelningai. Palankiai vertinamas organizacijos noras dalytis savo sukurtomis gèrybèmis (ar kapitalu), siekiant užsitikrinti savo išskirtinumą (veikla, organizacijos ženklu, gaminama produkcija) prieš kitus, užsiimančius tokia pačia veikla. Tai užtikrina jos galimybę išlikti ir išvengti nepalankaus valstybinių ar visuomeninių institucijų požiūrio.

\section{Literatūra}

Atkočiūnienè, Z. O. (2013). Žinių vadyba ir organizacijos darna: konkurencinio pranašumo aspektas. Elektroninis mokymasis, informacija ir komunikacija: teorija ir praktika, nr. 1, p. 15-27. Vilnius: VU leidykla.

Atkočiūnienè, Z. O., Radiunaitè, R. (2011). Žinių vadybos įtaka darnaus vystymosi reikšmèms ịgyvendinti organizacijoje. Informacijos mokslai, t. 58, p. 56-73. Vilnius: VU leidykla.

Bakanauskas, A., Vanagienė, V. (2012). İmonių socialinės atsakomybės gairès stiprinant prekès ženklo reputaciją. Vadybos mokslas ir studijos - kaimo verslų ir ju infrastruktūros plètrai. Kaunas: ASU leidybos centras, nr. 3 (32), p. $15-22$.

Bartkus, E. V., Grunda, R. (2011). Business Sustainability Assessment: Comparing Results of Two Studies. Inzinerine Ekonomika - Engineering Economics, nr. 22 (1), p. 32-40. Kaunas: Technologija.

Brower, H. H. (2011). Sustainable Development Through Service Learning: A Pedagogical Framework and Case Example in a Third World Context. Academy of Management Learning \& Education, vol. 10, no. 1, p. 58-76. Briarcliff Manor, NY: Acad.

Bruno, K., Karliner, J. (2002). Earthsummit biz: The Corporate Takeover of Sustainable Development. Food First Books. Oakland: CA.

Butkutè, A., Gotautienè, E. (2011). Ekologinis marketingas - konkurencinio pranašumo ir pridėtinès vertės garantas verslui. Profesinès studijos: teorija ir praktika, nr. 8, p. 101-108. Šiauliai: Šiaulių kolegijos leidybos centras.

Clifton, D., Amran, A. (2010). The Stakeholder Approach: A Sustainability Perspective. Journal of Business Ethics Springer, vol. 98, issue 1, p. 121-136. Dordrecht: NL.

Čiegis, R. (2008). Darnus vystymasis: aplinka, ekonomika, technologijos. Kaunas: UAB „Biznio mašinų kompanija“.

Čiegis, R., Gavenauskas, A. (2005). Darnaus vystymosi valdymas: etiniai aspektai. Tiltai, nr. 4, p. 31-38. Klaipėda: KU leidykla. 
Čiegis, R., Grunda, R. (2007). İmonès transformavimo ị darnią įmonę procesas. Organizacijų vadyba: sisteminiai tyrimai, nr. 44, p. 19-34. Kaunas: VDU leidykla.

Čiegis, R., Norkutè, R. (2012). Lietuvos bankų socialinė atsakomybė darnaus vystymosi kontekste. Organizacijų vadyba: sisteminiai tyrimai, nr. 63, p. 19-33. Kaunas: VDU leidykla.

Dagilienė, L., Gokienė, R. (2012). Socialinio audito raiška Lietuvoje. Apskaitos ir finansu mokslas ir studijos: problemos ir perspektyvos, nr. 1 (8), p. 44-48. Kauno raj.: Akademija.

Esty, D. C., Winston, A. S. (2009). Green to Gold. How Smart Companies Use Environmental Startery to Innovate, Create Value, and Build Competitive Advantage. USA.

Jochem, R. (2011). Sustainability modelling as an enterprise quality requirement. Current Issues of Business and Law, vol. 6, issue 1, p. 129-140. Vilnius: TTVAM.

Jusčius, V., Šneiderienė, A. (2013). İmonių socialinès atsakomybès įtaka regioninei plètrai. Regional Formation and Development Studies, no. 1 (9), p. 66-78. Klaipėda: KU leidykla.

Křupka, J., Provazníková, R. (2013). Modeling of Standards of Living in Euro zone Countries on the basis of Multiple Criteria Decision Analysis. Recent Researches in Applied Economics and Management. Business Administration and Financial Management, vol. 1, p. 425-432. Hellenic (Greek): WSEAS Press.

Leuenberger, D. (2006). Sustainable Development in Public Administration. A Match With Practice? Public Work Management \& Policy. Sage Publications, vol. 10, no. 3, p. 195-202. Prieiga internete: http://pwm.sagepub.com/ content/10/3/195.full.pdf+html [žiūrèta 201103 10].

Lodienè, D. (2011). Progreso ciklą skatinantys veiksniai darnioje organizacijoje. Vadybos mokslas ir studijos - kaimo verslu ir ju infrastruktūros plètrai, nr. 1 (25), p. 163-170. Kaunas: LŽŪU leidykla.

Orlitzky, M., Siegel, D. S., Waldman, D. A. (2011). Strategic Corporate Social Responsibility and Enviromental Sustainability. Business and Society. Sage Publications, vol. 50 (1), p. 6-27.

Pilipavičius, V. (2012). Darnaus darbo vietų vystymo kaimiškuose regionuose teorinès prielaidos. Žemès ūkio mokslai, t. 19, nr. 3, p. 192-202. Vilnius: Lietuvos mokslų akademija.

Reiser, D. B. (2011). Benefit Corporations - A Sustainable Form of Organization? NY: Brooklyn Law School. Prieiga internete: http://papers.ssrn.com/sol3/papers.cfm?abstract_id=2144795 [žiūrèta 201401 20].

Šimanskienė, L., Paužuolienè, J. (2011). Darnaus vystymo koncepcijos suvokimas organizacijose. Vadybos mokslas ir studijos - kaimo verslu ir ju infrastruktūros plètrai, nr. 2 (26), p. 241-247. Kaunas: LŽŪU leidykla.

Štreimikienè, D., Vasiljevienè, N. (2004). Etiniai darnaus vystymosi aspektai ir jų ryšys su socialinėmis ir aplinkosauginemis darnaus vystymosi dimensijomis. Organizacijų vadyba: sisteminiai tyrimai, nr. 32, p. 189-206. Kaunas: VDU leidykla.

Гаврилов, Г. Г. (2012). Проблемы системной трансформации корпоративной стратегии устойчивого развития. Современные наукоемкие технологии. Региональное приложение, № 1 (29), с. 16-22. Издается: РФ, Ивановским государственным химико-технологическим университетом.

\title{
SUSTAINABILITY AND BENEFIT FROM THIS TO ORGANIZATIONS
}

\author{
Ligita Šimanskiené, Arnoldas Petrulis \\ Klaipėda University (Lithuania)
}

\section{Summary}

There is the one of the biggest problem in the world- not sustainable development of countries, regions. The governments of different countries were trying to solve economical differences between some countries and regions only using economic measures in last century. It should be noted that economic development orientations and concepts cannot satisfy the humanity's needs and they have only a limited application spectrum in environmental protection studies. The situation supposes the necessity to propose new approaches and to define the essence of economic theory, its potential role and tasks, in solving issues related to critical human existence and civilization survival in the future. Sustainable development is based on three dimensions: economic development, social development, and environmental protection. But still there are big scientific problem - how to change mentality of people through the world? How to find measures that 
would be understandable for everybody? How to change people thinking to use less? How to explain for managers of organizations, that to be sustainable - to be successful? These and other questions were analyzed in this article. The aim of this paper is to describe benefit of sustainable development in organizations. Object of research - sustainable organizations. The tasks of the article: to analyze the concepts of sustainable development in organizational level; to analyze concept of sustainable organization and to show benefit for organizations to sustainable. Used methods are- the analysis of scientific articles, comparison, and observation.

KEY WORDS: sustainability, organization, benefit.

JEL CODES: Q56, Q 01, M 10 